\title{
Uma Abordagem Cognitiva sobre o Haiti: o papel do ambiente psicológico na construção de imagens no contexto da MINUSTAH (2004-2016)
}

Recebido: 30-11-2017

Aprovado: 05-07-2018

Fábio Albergaria de Queiroz ${ }^{1}$ Thais de Castro de Barros ${ }^{2}$

\section{Introdução}

O Haiti é um caso interessante e emblemático na história do continente americano: foi a primeira república governada por negros, o segundo país do Novo Mundo a ter sua independência declarada e o primeiro a derrotar o exército de Napoleão Bonaparte. ${ }^{3}$

No entanto, mesmo que o Haiti tenha começado sua história independente com ideais progressistas para a época e, igualmente, com feitos notáveis, o país passou por sucessivos quadros de instabilidade política, fragilização das instituições e do Estado de Direito e desastres naturais de grande magnitude que, sobrepostos, em um longo continuum histórico, agravaram cronicamente sua situação.

Assim, visto como uma possível ameaça à segurança regional, sobretudo, a partir dos anos $1990^{4}$ na medida em que crescia a percepção de que o país qualificava-se como um caso

\footnotetext{
${ }^{1}$ Pós-Doutorado em Relações Internacionais pela Universidade de Brasília. Professor no curso de Relações Internacionais da Universidade Católica de Brasília. Contato: fabioaq@ hotmail.com

${ }^{2}$ Internacionalista e mestranda em Desenvolvimento e Cooperação Internacional na Universidade de Lisboa. Contato: tdecastro.barros@gmail.com

${ }^{3}$ Em 1803, determinado a não perder a mais produtiva possessão colonial francesa na América, Napoleão Bonaparte enviou, sob o comando de Charles Leclerc, um grande contingente militar, mais de 20 mil homens, para conter a insurreição na pequena ilha centro americana. Como veremos adiante, apesar do êxito inicial da contraofensiva, os revolucionários haitianos contaram com a liderança de Jacques Dessalines, um ex-escravo, para derrotar as forças do exército francês na batalha de Vertières e, finalmente, proclamar a independência. Contudo, o reconhecimento só viria em 1825, mediante pagamento de uma indenização de 150 milhões de francos a França, o que não impediu que o feito servisse de inspiração a outras revoltas no continente americano. ${ }^{4}$ Em 1990 a presença da ONU foi requisitada pelo governo provisório do país. O pedido foi prontamente aceito dadas as circunstâncias de crescente deslocamento populacional haitiano para países vizinhos (ONU, 2016).
} 
de Estado Falido ${ }^{5}$ (Fukuyama, 2005; Rocha, 2007; Junior e Góes, 2010; Petrus, 2012), uma coalizão entre ONU, Comunidade do Caribe (CARICOM) e Organização dos Estados Americanos (OEA) foi formada buscando somar esforços em prol de se conter o estado de caos que se instalara. Dali em diante, o Haiti passaria por várias intervenções resultantes do trabalho conjunto das três instituições internacionais.

O ápice deste processo ocorre quando, com a renúncia do presidente Jean-Bertrand Aristide, em 29 de fevereiro de 2004, o seu substituto, Bonifácio Alexandre, requisita o apoio das Nações Unidas para estabilizar o país. ${ }^{6}$ Em resposta, no dia 1 de junho de 2004, a ONU, por meio da resolução 1542 de seu Conselho de Segurança, estabelece o mandato da Missão das Nações Unidas para a estabilização no Haiti (MINUSTAH, sigla derivada do francês Mission des Nations Unies pour la Stabilisation en Haiti).

Desde então, a MINUSTAH operou no país nas seguintes áreas: (1) segurança e estabilidade; (2) processo político (sobretudo dando apoio em processos eleitorais e auxiliando no fortalecimento das instituições políticas) e; (3) observância dos Direitos Humanos (ONU, 2016).

Mas, apesar do longo período de atuação da MINUSTAH, conforme a análise de dados do Fragil States Index (2016), o Haiti permanece em estado de alerta, uma vez que ainda apresenta dificuldades em desenvolver suas instituições políticas e impulsionar o crescimento dos indicadores sociais e econômicos. ${ }^{7}$

\footnotetext{
${ }^{5}$ O artigo 'Saving Failed States' de Gerald Helman e Steven Ratner, publicado na Foreign Policy, em 1992, é considerado o marco inicial dos debates sobre o tema. Na ocasião eles afirmaram que "os Estados em vias de fracasso prometem se tornar uma faceta familiar da vida internacional" (p.18). Desde então, a ideia de "Estados fracassados' vem ganhando proeminência no meio acadêmico. Vários são os adjetivos utilizados para denominálos: Estados Fracos, Fracassados, Falidos, em colapso, nações-párias. Para Jackson (1998), por exemplo, os Estados Falidos, num sentido mais geral, são aqueles que não podem ou não irão salvaguardar domesticamente condições mínimas, como paz, ordem e segurança. Já Rocha (2007) avança no esforço de refinamento conceitual ao propor diferenças semânticas na designação deste atores. Na tipologia por ele proposta, Estados colapsados são aqueles nos quais a situação de anarquia prevalece dentro do território, parte do qual é controlado por senhores da guerra, que são capazes de comandar pessoas e recursos em prol de seus próprios grupos. Estados fragmentados são aqueles nos quais um Estado legítimo subsiste, e tem sua autoridade reforçada pela comunidade internacional, mas é incapaz de controlar totalmente seu território e/ou população. Já Estados frágeis são aqueles em que a legitimidade não é diretamente contestada por entidades subnacionais, nem por agências internacionais, mas cuja capacidade governativa é extremamente baixa - ou cujas elites não estão interessadas em prover bens públicos em quantidade suficiente para garantir um mínimo bem-estar a sua população. Não obstante estas variações, os termos aqui utilizados não seguem uma única adjetivação, o que não implica prejuízos de interpretação, pois, como dito, estas designações se referem ao mesmo objeto: países em situações desconfortáveis com a qualificação como Estado de Direito.

${ }^{6}$ Para o estabelecimento do mandato de uma missão de paz faz-se necessário a observância de três princípios normativos: 1) o consentimento das partes envolvidas; 2 ) a neutralidade e imparcialidade das forças ocupantes e, por fim; 3) o uso mínimo da força, via de regra somente em casos de legítima defesa.

${ }^{7}$ O Haiti é o país mais pobre das Américas e um dos mais pobres do mundo, o $163^{\circ}$ entre 187 países avaliados no relatório de 2016 do Programa das Nações Unidas para o Desenvolvimento (PNUD) sobre Índice de Desenvolvimento Humano. Para maiores informações ver: http://hdr.undp.org/en/countries/profiles/HTI
} 
Após o fim do mandato presidencial de Michel Martelly, em 6 de fevereiro de 2016, por exemplo, o país ainda não havia conseguido cumprir o prazo para novas eleições chegando a ter dois presidentes interinos, até que, finalmente, no fim daquele ano, uma nova eleição ocorresse (Taft-Morales, 2017, p 1). No dia 12 de abril de 2017, no entanto, foi aprovada uma resolução que determinou a saída gradual da MINUSTAH do Haiti. Mas, tendo em vista a persistente necessidade de fortalecimento do Estado de Direito no país, um dos problemas centrais do Haiti continua sendo a dificuldade de se desvincular totalmente da ajuda externa ${ }^{8}$.

Nesse contexto, Taft-Morales (2017, p.4) aponta que apesar de um começo difícil marcado por denúncias de abusos e uso excessivo da força - com as eleições, em 2006, a MINUSTAH ganhou novo fôlego, graças ao apoio do presidente eleito, René Préval, aos esforços de estabilização do mandato. Hamann (2009) e Dorn (2009) complementam esta percepção ao afirmarem que, apesar dos percalços, a MINUSTAH conseguiu atingir certos níveis de sucesso que outras missões no país não lograram, como a ocupação militar de bairros violentos em Porto Príncipe.

Essas idiossincrasias passam a ser importante objeto de investigação considerando-se que vultosas somas foram despendidas desde a criação da MINUSTAH sem que, em contrapartida, o país tenha conseguido avançar significativamente quanto à sua capacidade de agência enquanto unidade soberana (Seitenfus, 2014, Taft-Morales, 2017) ${ }^{9}$. Soma-se à variável eficiência dos gastos, o fato de que foi crescente entre os haitianos a percepção da MINUSTAH como uma ocupação estrangeira de seu território e, por conseguinte, também o foram os movimentos contestatórios da Missão (Heine e Thompson, 2011; p.11).

Assim, a partir do contexto apresentado, partimos da premissa de que se torna relevante contemplar, na multiplicidade de variáveis que fazem parte do State-building ${ }^{10}$ de

\footnotetext{
${ }^{8}$ No momento em que o artigo foi escrito, a MINUSTAH ainda estava em andamento, por isso nosso recorte temporal ir até 2016. Contudo, cumpre destacar que a Resolução 2350(2017) do Conselho de Segurança das Nações Unidas determinou que a Missão findasse suas atividades em 15 de outubro de 2017. Estabeleceu-se, ainda, que a partir do dia 16 de outubro entraria em vigor, em substituição à MINUSTAH, a MINUSJUSTH (Missão das Nações Unidas de Apoio à Justiça no Haiti), missão sem o componente militar, composta apenas por civis e unidades de polícia objetivando: 1) monitorar a situação de direitos humanos e; 2) fortalecer o diálogo político e as instituições judiciais e penais do país.

${ }_{9}^{9}$ De acordo com dados da ONU (2016) foram gastos, anualmente, na MINUSTAH, algo em torno de US\$346 milhões.

${ }^{10}$ Os termos nation-building e State-building, como processos, se referem a unidades ontológicas distintas, porém indissociáveis: a nação e o Estado, respectivamente. Logo, enquanto o nation-building envolve a construção de símbolos e valores ligados à ideia de nação, sobretudo, após os processos de descolonização, o State-building, por seu turno, está relacionado à construção "das instituições políticas ou mesmo daquelas designadas para promover o desenvolvimento econômico" (Gomes, 2009; p.312).
} 
um país, neste caso, do Haiti, os aspectos cognitivos que moldaram, e ainda moldam o que a literatura em modelos de análise em processos decisórios convencionou chamar de ambiente psicológico.

Dentre os elementos que o compõem, será dado um enfoque maior a duas variáveis independentes principais: o prisma atitudinal - formado por fatores societais, como ideologias, legado histórico, religião e personalidades dos tomadores de decisão - e as imagens construídas - as percepções que as elites decisórias têm do cenário oriundo do prisma atitudinal - pois, conforme será explicado adiante, as mesmas podem ter um peso relevante no processo de construção das agendas propostas pela MINUSTAH e, também, nas ações posteriores da ONU no país.

Logo, a Teoria Cognitiva, da qual essas variáveis são elementos constituintes, coloca em destaque, para além dos clássicos fatores objetivos, comumente analisados em processos decisórios, os elementos psicológicos e culturais - ou estruturas de conhecimento subjetivas, como as define Boulding (1961) - como ordenadores de preferências e guias de comportamento capazes de moldar percepções e, destarte, influenciar na tomada de decisões (Queiroz, 2013).

Dessa forma, com base nos citados postulados do referencial teórico selecionado, o artigo buscará respostas para a seguinte pergunta de pesquisa: por meio da abordagem cognitiva, como e em que medida o prisma atitudinal haitiano e as imagens resultantes interferiram na evolução do desenvolvimento das agendas propostas no mandato da MINUSTAH?

Para tanto, a partir de obras que integram a literatura mainstream (Sprout e Sprout, 1957; Boulding, 1961; Brecher et al, 1969) e de subsídios fornecidos por estudos de caso sobre o papel da abordagem cognitiva em processos decisórios (Brecher, 1972; Silva, 1995; Queiroz, 2013), partimos da hipótese relacional de que quanto maior for a convergência entre os elementos constituintes do ambiente psicológico do universo de pesquisa (neste caso, o prisma atitudinal e as imagens construídas) maiores serão seus impactos no desenvolvimento das agendas propostas no âmbito da missão de paz.

Para testar a validade da hipótese levantada, esse exercício epistemológico está dividido em três partes. Inicialmente, discorremos sobre a importância da Teoria Cognitiva nos estudos de política externa. Por meio do conceito de prisma atitudinal, na segunda etapa, fazemos uma análise dos acontecimentos históricos e elementos sociopolíticos que moldaram as imagens haitianas. 
Por fim, na terceira parte aplicamos o instrumental teórico-conceitual ao estudo de caso, de forma a buscar inferências descritivas sobre o papel das imagens projetas pelas elites decisórias haitianas e pela ONU na execução da MINUSTAH recorrendo, para tanto, à análise amostral de discursos presidenciais e de resoluções da Organização.

\section{Ambiente Psicológico, Política Externa e Processos Decisórios}

Para os propósitos deste trabalho cabe destacar a contribuição de Harold e Margaret Sprout (1957) ao estabelecerem a distinção entre o chamado ambiente operacional - o cenário real, onde os fatos domésticos e externos estão acontecendo e, ao mesmo tempo, moldando as linhas de procedimento e conduta internacional - e o ambiente psicológico, este último, como antecipado, integrado por imagens, ideias, valores, crenças e percepções. Como resultado deste esforço intelectual, o exame do ambiente psicológico sobre o sistema operacional assumiu crescente importância e tornou-se um lídimo objeto dos estudos de processos decisórios e política externa (Queiroz, 2013, p. 28).

O arcabouço conceitual elaborado pelos Sprout (1957) consolidou-se como um importante marco teórico e seguiu influenciando os estudos que lhe sucederam. Michael Brecher et al (1969), por exemplo, retomaram o conceito de ambiente psicológico em suas investigações sobre as variáveis subjetivas que contribuem para a compreensão do processo decisório e, também, sobre o poder de filtragem das imagens. Nesse sentido, apontaram que o ambiente operacional, indiscutivelmente, afeta o resultado das decisões tomadas, porém, só depois de filtrado pelas imagens e atitudes daqueles que as tomam, o que reforça o papel das percepções destes atores como um elemento fundamental na análise da política externa.

Em sua pesquisa sobre Israel, Brecher (1972) avança significativamente em termos de inserção dos aspectos culturais no escopo dos processos decisórios em política externa. Como uma de suas contribuições - aquela que nos será de grande valia para o desenvolvimento dos argumentos que fundamentam este artigo - ele faz a distinção entre o que ele define como prisma atitudinal, a saber, a ideologia e as características de personalidade ou predisposições psicológicas da elite decisória, e as imagens do ambiente, por assim dizer, as percepções que, de acordo com sua tipologia, representam o mais importante input para a formação da política externa.

Assim, vemos o método cognitivo de Brecher et al. (1969, p. 81) e Brecher (1972) fortemente baseado na noção de inputs e outputs. Nesse sentido, os inputs são compostos 
pelos elementos da figura 1, enquanto que os outputs representam a substância dos atos e decisões, ou seja, os resultados práticos do processo de inputs.

Figura 1- Os Inputs Cognitivos

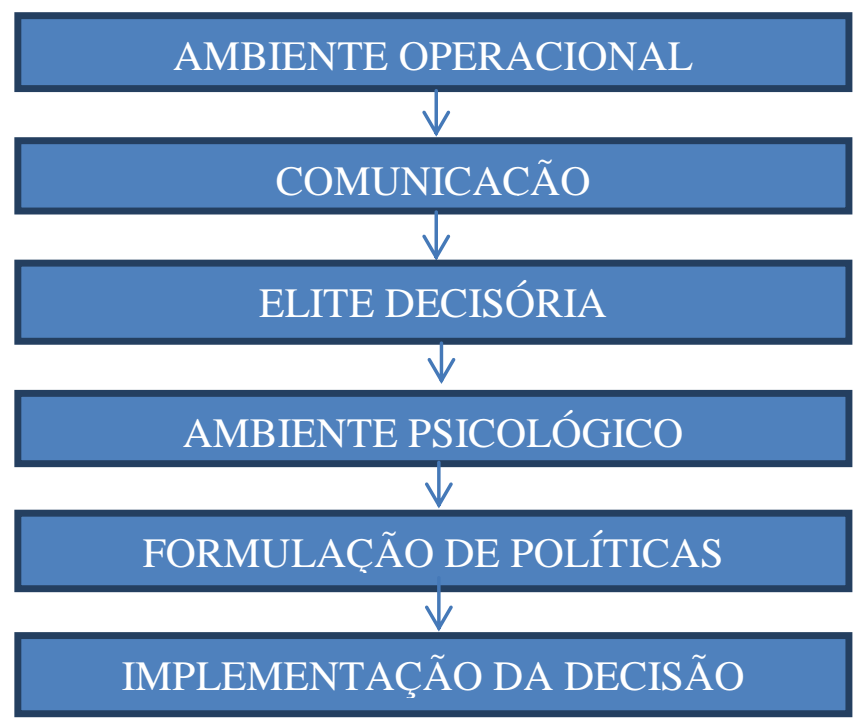

Fonte: Brecher et al. (1969, p.80). Elaborado pelos autores (2016).

Aqui, observando o processo de inputs, constata-se que os mesmos começam com um ambiente operacional, onde as decisões de política externa são tomadas. Ainda nesse sentido, o ambiente operacional é constituído por dois grupos de fatores: externos e internos. Os fatores externos referem-se às condições e relacionamentos que ocorrem fora das fronteiras estatais, enquanto as variáveis internas dizem respeito a uma avaliação das capacidades (militares, políticas, econômicas) de elites e outros grupos de interesse concorrentes (Brecher et al. 1969, p. 82).

$\mathrm{Na}$ análise cognitiva da política externa, é ainda necessário, além da análise do ambiente operacional, um exame sobre os mecanismos de comunicação com o sistema político e sobre a adequação, precisão, nível de competência e objetivos do fluxo de informações no ambiente operacional (Brecher et al. 1969, p. 86). É aqui, segundo os autores, que começa a ser observada a equivalência entre a realidade e as imagens projetadas pelas elites.

Logo, o exame psicológico do ambiente operacional haitiano a partir das imagens projetadas pelos elementos ontológicos selecionados para este estudo - o Governo haitiano e a ONU - tendo, no plano teórico, o prisma atitudinal como catalisador de tais posicionamentos, se torna relevante para uma acurada percepção acerca das ações tomadas no âmbito da MINUSTAH ao longo de nosso recorte temporal. 


\section{O Papel do Prisma Atitudinal Haitiano: do processo de independência à atuação da MINUSTAH}

Conforme visto, o prisma atitudinal é composto, em linhas gerais, por elementos históricos, ideológicos e cognitivos que, conjuntamente, ajudam a definir as imagens a serem projetadas nos processos decisórios.

Nesse sentido, Gorender (2004), Popkin (2011, p. 162) e Seitenfus (2014) apontam que um dos maiores fatores para a atual crise haitiana remonta ao isolamento decorrente da "ousadia" do país em ter desafiado a lógica do Sistema Internacional colonial vigente ao derrotar o exército de Napoleão Bonaparte se tornando, assim, o primeiro país governado por ex-escravos e o segundo país a declarar a independência na América. ${ }^{11}$ A partir desses argumentos, surge, então, a questão: de que forma o Haiti internalizou esses acontecimentos históricos no processo de construção de sua imagem recente?

É importante destacar que, para fins de prisma atitudinal, por uma questão de extensão e metodologia, optou-se por uma análise que leve em conta a variável 'legado histórico', apesar das características de personalidade serem claramente observáveis nos discursos e nessa própria descrição histórica.

Baseado em documentos das Nações Unidas e em estudos acadêmicos de cunho histórico sobre o Haiti, sintetizamos os principiais eventos que contribuíram para moldar o prisma atitudinal haitiano, desde o processo de independência até os desdobramentos da MINUSTAH ao ano que antecede seu fim.

Temos, assim, a luta pela independência, de 1789 até 1804, como um processo de profundas repercussões, nascido da esperança de que, com a Revolução Francesa de 1789, haveria a abolição da escravidão no território que viria a se tornar o Haiti que hoje conhecemos (Popkin, 2011, p. 21).

Com a frustração da expectativa formada, começou a ocorrer na colônia francesa uma série de revoltas de escravos, que culminou na fuga e destruição dos meios de produção. No período, a aversão ao branco foi um sentimento muito forte e importante para a independência do Haiti.

Ao longo da luta de independência, os insurgentes passaram a usar táticas de incêndio e toda as vezes que encontravam escravos brutalmente assassinados, faziam o mesmo com os

\footnotetext{
${ }^{11} \mathrm{O}$ primeiro foram os Estados Unidos, em 1776.
} 
brancos. Essa tática se mostrava tão cruel quanto à das forças francesas, que temendo as baixas em batalhas, passou a praticar uma política de extermínio. ${ }^{12}$

No dia 29 de dezembro de 1803, é escrita a declaração de independência por Louis Felix Boisround-Tonerre que, na ocasião, chegou a declarar que o documento deveria ser escrito sobre a pele de um branco utilizando-se, para tanto, o crânio do mesmo como tinteiro e o sangue como tinta (Popkin, 2011, p.135). Em 31 de dezembro do mesmo ano sai à declaração definitiva e em 01 de janeiro de 1804 é declarada a independência do Haiti.

Ainda, quanto ao processo de independência, além da rejeição ao branco, é importante destacar o papel do vodu enquanto elemento socialmente agregador. Em meio à violência ao qual o processo de independência esteve inserido, o uso desta prática religiosa antes de irem às batalhas era comum, tendo vários sacerdotes vodus (os chamados hougan) como líderes das revoltas (Seitenfus, 2014, p.54). Complementarmente, Laguerre (1989, p.1) relata que os hougan incentivavam os escravos a se rebelarem contra os franceses sob o argumento de que, por meio de rituais de possessão, os insurgentes contariam com a proteção dos espíritos. ${ }^{13}$ Assim, frequentemente apontado como um dos elementos responsáveis pela bem-sucedida rebelião que libertou o Haiti do domínio francês,o vodu trouxe coesão social - ao agregar em torno de uma causa comum diversas etnias de escravos - e a esperança de vitória, tão necessários ao movimento. A importância ontológica desta prática religiosa consolidou-se de tal maneira que persiste, ainda hoje, como um elemento societal ${ }^{14}$ de grande importância ${ }^{15}$.

Já no pós-independência, Jean Jacques Dessalines se tornou o primeiro chefe de Estado da primeira nação governada por negros. O mesmo criou um sistema de governo que dividiu o povo em duas categorias: trabalhadores e soldados. Toda a pompa que Dessalines ostentava e a maneira como conduziu a política no país fizeram com que seus outrora

\footnotetext{
${ }^{12} \mathrm{Na}$ ocasião em que o comandante francês, General Donatien Marie Joseph de Rochambeau (1755-1813), mandou executar 500 negros e os fez cavar suas próprias covas, Dessalines enforcou e deixou à mostra nas cidades haitianas 500 brancos (Seitenfus, 2014, p. 47).

${ }^{13}$ Languerre $(1989$, p. 2) aponta, ainda, que, durante toda história do Haiti, a influência do vodu se perpetuou através de sociedades secretas influentes na política e na justiça do país e até em grupos armados, como o movimento de resistência "Kako" contra a ocupação norte-americana entre 1915-1934.

${ }^{14}$ Cumpre ressaltar que os termos societal e social, utilizados como sinônimos em muitos casos, denotam dinâmicas distintas. Enquanto o primeiro se refere às coletividades e suas identidades, o segundo diz respeito a indivíduos per si e está diretamente vinculado à dimensão econômica de suas inter-relações enquanto comunidades.

${ }^{15}$ Apesar de sua importância societal, o vodu foi reconhecido como prática legal somente em 2003, por decreto presidencial de Jean-Bertrand Aristide, o que o alçou ao patamar de igualdade com as outras religiões oficiais do país. Resultado de um grande sincretismo entre elementos de cultos africanos com o cristianismo, sua prática é tão popular que costuma-se dizer que $100 \%$ dos haitianos praticam o vodu, o que reforça seu papel como elemento promotor de coesão identitária por estar profundamente atrelado às tradições e valores nacionais.
} 
seguidores o abandonassem e, em 1806, levassem o Haiti a uma revolução que terminou com o seu assassinato (Harrison, 1985, p.105).

Deste quadro, um ponto de inflexão na história haitiana começa: o incipiente país dava seus primeiros passos em meio à dura repressão e instabilidade, fatores esses constantes ao longo de toda sua história. Esse colapso fez com que o Haiti chegasse até mesmo a ser dividido em dois governos: um ao norte, o Estado do Haiti, onde a economia seguia os moldes agroexportadores coloniais, e outro ao Sul, a República do Haiti, conhecido pelos avanços sociais, economia de subsistência e reforma agrária. Esse regime durou 13 anos.

Com a reunificação em 1818, o sistema econômico adotado passa a ser o de fazendas de subsistência. Tal tomada de decisão foi decisiva para o fracasso econômico da economia haitiana, que perdeu os principais parceiros internacionais. Outro fator decisivo para o empobrecimento do país foi a preocupação com possíveis tentativas por parte da França de retomar o território haitiano. Sendo assim, Jean-Pierre Boyer (1776-1850), o segundo chefe de Estado do Haiti (1818-1843), opta por se endividar e, em 1825, compra o reconhecimento da França por 150 milhões de francos, pagos em um prazo de cinco anos (Gorender, 2004).

A partir de 1843, recorrentes golpes de Estados ocorreram a ponto de, em um período de 72 anos, de 1843 a 1915, apenas um governante conseguir cumprir seu mandato. O Estado haitiano, portanto, desde seu início como país independente já se encontrava, sobremodo, vinculado aos interesses pessoais da elite decisória. E o fato é que ainda hoje pugna, de certo modo, pugna por essa independência, paradoxalmente, dentro de um contexto de total dependência.

Outro ponto marcante é o caráter desestabilizador do Exército que, formado majoritariamente por negros, acabou garantindo que a maioria dos governantes fosse negra, o que acentuou as divisões e revanchismos raciais por um longo período.

Ademais, a persistente dependência externa e a má administração financeira seriam tão grandes a ponto de, no começo do século XX, levar franceses, americanos e alemães - ante a resultante fragilidade do Estado de Direito - a competir por uma posição dominante no país. Além disso, com o irromper da Primeira Guerra Mundial e os fundados temores de uma intervenção alemã no Haiti e, diante da crise política que enfrentava o então presidente, Guillaume Sam, os EUA decidem realizar uma ocupação militar no país em 28 de julho de 1915.

Com a invasão americana, reformas aconteceram: os mulatos voltaram ao poder, substituiu-se o exército por uma força policial irrisória e, concomitantemente, reforçou-se a 
imagem do autoritarismo na cultura haitiana. Apesar disso, nenhuma reforma durável, de caráter estrutural, logrou êxito (Harrison, 1985, p.109).

Favorecido pela Política de Boa vizinhança ${ }^{16}$ de Franklin Delano Roosevelt, eleito presidente dos EUA em 1933, o mulato Stenio Vicent consegue avançar nas negociações para a retirada norte-americana do país caribenho. Vicent continuou no poder até 1941, de forma autoritária, até que o legislativo resolveu, sem consulta popular, validar seu terceiro mandato. Os EUA se mostraram contrários a isso e, por fim, Elie L. Lescot foi eleito. Apesar das boas expectativas criadas, Lescot acabou por repetir a prática recorrente de seus antecessores: preocupou-se mais em se manter e desfrutar do poder do que em fazer melhorias no país.

Assim, até a ascensão da Ditadura Duvalier (1957-86), o Haiti passou por diversos golpes militares e diferentes governos. ${ }^{17}$ O governo de François Duvalier (1957-71), o Papa $D o c$, instaurou um regime de exceção, o que acentuou ainda mais a já crônica instabilidade no país. Sob seu comando, a ação policial dos tontons macoutes (bichos-papões) foi um importante elemento da coerção ditatorial.

Nessa época houve uma supervalorização da religião vodu por todo o Haiti, inclusive pelos tontons macoutes. Papa Doc, percebendo a grande influência da religião no país, se aproximou dos principais líderes hougan e suas respectivas rede de contatos buscando respaldo e apoio político. Seguindo essa mesma linha, os tontons macoutes, ou Voluntários da Segurança Nacional ${ }^{18}$, eram, em sua maioria, membros da igreja e das seitas vodus e utilizavam dessa prática religiosa como método de captura e tortura (Laguerre, 1989, p.2).

Ademais, além da forte atividade repressora, o Governo Duvalier foi marcado por certa omissão quanto às condições econômicas e sociais do país. Após a morte de Papa Doc, em 21 de abril de 1971, pouco depois de ter promulgado uma constituição (1964) que lhe dava mandato vitalício, seu filho Jean Claude Duvalier, conhecido como Baby Doc, assume o poder aos 19 anos de idade.

Baby Doc se proclamou Presidente perpétuo do país e até conseguiu trazer certo progresso econômico, devido, sobretudo, aos baixos salários haitianos que viraram um atrativo às indústrias de todo o mundo, e também pelo fato de o Haiti, por ser um dos países

\footnotetext{
${ }^{16}$ A chamada Política de Boa Vizinhança instaurou uma mudança paradigmática na relação dos Estados Unidos com a América Latina ao propor a substituição da política intervencionista de Washington, recorrente desde o final do século XIX, em prol de uma agenda de ação pautada, sobremodo, na colaboração econômica e militar com os países da região com o objetivo de manter a estabilidade política no continente e assegurar a liderança norte-americana em seu entorno estratégico.

17 É interessante notar que, nesse período conturbado, o autoritarismo governamental, a corrupção e as constantes tentativas dos detentores de poder em perpetuar o status quo ocorreram mesmo nos governos que fizeram importantes reformas e propiciaram melhoras para a economia haitiana.

18 Milice de Volontaires de la Sécurité Nationale (MVSN).
} 
mais pobres da região, ter passado a receber constate ajuda humanitária. A queda de Baby Doc, em 1986, deposto por um golpe militar, representou o começo dos esforços significativos rumo a um futuro democrático.

É importante destacar que a partir desse novo momento político, a crise no Haiti passa a ser catalisada pela frustrada tentativa de transição de poder de um modelo de pouca participação popular nas tomadas de decisão para um modelo mais inclusivo (Seitenfus, 2014, p. 66). E é esse um componente em que as operações de paz no Haiti tem copiosamente falhado em lidar.

Mesmo com a saída de Baby Doc e desse novo contexto, o país continuou tendo dificuldade em construir um governo democrático passando, tal qual em períodos anteriores, por sucessivos golpes. ${ }^{19}$

O século XXI não foi diferente para o Haiti: o presidente Jean-Bertrand Aristide é acusado de fraudar as eleições presidenciais e parlamentares de $2000 .^{20}$ Aristide também foi acusado de corrupção, envolvimento no tráfico de drogas e de sustentar gangues armadas no país (Viana, 2011, p.24-25).

Com o enfraquecimento do diálogo entre o presidente e a oposição, a mesma passou a ser perseguida pela polícia haitiana e grupos armados pró-governo. No final de 2003, surge um novo movimento oposicionista formado por partidos políticos, membros da Sociedade Civil e pelo setor privado exigindo, dentre outras demandas, a renúncia de Aristide (ONU, 2016).

Um grande conflito armado começa, então, a tomar conta do Haiti e Aristide abandona o país. Com a renúncia, o presidente da Suprema Corte haitiana, Boniface Alexandre, assume interinamente o governo. Imediatamente após sua posse, na noite do dia 29 de Fevereiro de 2004, Boniface encaminhou às Nações Unidas um pedido de ajuda para estabilizar o país e que incluía a autorização para a entrada de tropas no país.

Solidário com o pedido, o Conselho de Segurança das Nações Unidas decide aprovar a Resolução 1529 autorizando a atuação da Força Interina Multinacional (ONU, 2016). Ainda diante de um ambiente pouco estável, a atual operação de paz da ONU no Haiti, MINUSTAH, começa no dia 30 de abril de 2004, com a Resolução 1542 do Conselho de Segurança.

\footnotetext{
${ }^{19}$ Começam, assim, seguidas operações de paz da ONU: a United Nations Observer Group for the Verification of the Elections in Haiti (ONUVEH); a International Civilian Mission in Haiti (MICIVIH); a United Nations Mission in Haiti (UNMIH); a United Nations Support Mission in Haiti (UNSMIH); a United Nations Transition Mission in Haiti (UNTMIH); a United Nations Civilian Police Mission in Haiti (MIPONUH), a MINUSTAH e, atualmente, a United Nations Mission for Justice Support in Haiti (MINUSJUSTH).

${ }^{20}$ Jean Aristide foi o primeiro presidente democraticamente eleito após o golpe militar que derrubou a ditadura Duvalier. Após o fim do governo de Préval, Aristide é novamente eleito nos anos 2000.
} 
É importante destacar um agravante para a situação no Haiti e que exigiu maiores esforços da MINUSTAH e do governo do país: o terremoto de 7.2 de magnitude na Escala Richter $^{21}$, em 2011, que deixou aproximadamente 200 mil mortos, segundo dados oficiais da ONU (2016).

Assim, com base nos elementos identificados ao longo dos períodos históricos narrados, faz-se necessário, para os propósitos deste artigo, entendê-los quanto a sua capacidade de projeção, via prisma atitudinal, nas imagens hodiernamente projetadas pelas elites decisórias. A figura abaixo traz uma síntese dos principais elementos constitutivos do prisma atitudinal do Haiti ao longo do recorte temporal analisado:

Quadro 1 - Quadro do Prisma Atitudinal Haitiano

\begin{tabular}{|l|l|}
\hline \multicolumn{1}{|c|}{ PRISMA ATITUDINAL HAITIANO } \\
\hline$\checkmark$ Raiz religiosa fundamentada na prática do Vodu \\
\hline$\checkmark$ Desavenças e desigualdades raciais entre negros e mulatos \\
\hline$\checkmark$ & Dificuldade de definição de uma agenda de interesse nacional \\
\hline$\checkmark$ & Desarticulação política \\
\hline$\checkmark$ & Corrupção \\
\hline$\checkmark$ & Violação sistemática dos Direitos Humanos \\
\hline$\checkmark$ & Desgaste das Forças Armadas haitianas, e por consequência, das instituições de segurança \\
nacionais & Autoritarismo Governamental \\
\hline$\checkmark$ & Presença substancial nos discursos de um país pobre e dependente da ajuda externa. \\
\hline$\checkmark$ & Tentativas fracassadas de estabelecimento de instituições democráticas \\
\hline$\checkmark$ & Percepção da necessidade de reforma das instituições políticas, econômicas e de segurança \\
do país.
\end{tabular}

Fonte: Elaborado pelos autores (2016).

No que concerne ao primeiro elemento - forte vínculo com o vodu - vê-se não apenas o seu papel histórico na coesão social e societal para a revolução, mas também sua incorporação pelas instituições do Estado, como as forças policiais. ${ }^{22}$

\footnotetext{
${ }^{21}$ A Escala Richter ou de Magnitude local é uma escala logarítmica, de base 10, utilizada para qualificar a magnitude de movimentos sísmicos. No caso do Haiti, o terremoto de 7.2 foi considerado de grande magnitude (capaz de provocar danos graves em amplas extensões).

${ }^{22}$ Abundam relatos de que os tontons macoutes utilizavam, frequentemente, de técnicas dessa prática religiosa para auxiliar na captura de dissidentes durante a ditadura Duvalier (LAGUERRE, 1989).
} 
A força do vodu é comprovada pelos dados demográficos da CIA (2016). Segundo a agência $54.7 \%$ da população haitiana se declara católica, seguida de $28.5 \%$ de protestantes. No entanto, a maioria dos haitianos praticam rituais do vodu em adição a outras religiões. Isso é explicado pelo crescente fluxo de ajuda humanitária, vindas em sua maioria, segundo Seitenfus (2014, p.57), de instituições religiosas cristãs. Essas instituições oferecem assistência básica ao povo em troca da aderência religiosa, o que acabou resultando em uma interessante fusão entre diferentes elementos religiosos.

Quanto às desigualdades raciais, tem-se que $95 \%$ da população é negra e $5 \%$ se declaram mulatos ou brancos (CIA, 2016). Ademais, observando-se a história é possível constatar que a minoria mulata tem uma instrução maior e tem se perpetuado com frequência no poder. Além disso, com base nos relatórios de Direitos Humanos sobre o mandato da MINUSTAH, nota-se a recorrência frequente ao estupro, sobretudo de mulheres com traços da raça branca, o que revela os resquícios das desavenças raciais.

Já a estabilidade política parece só ter ocorrido em governos autoritários, marcados por lideranças que apresentaram não só o individualismo como uma característica, mas também corrupção e massiva violação dos Direitos Humanos.

A dificuldade e definição de um interesse nacional claro, por sua vez, está fortemente ligada à instabilidade política e à prevalente organização social centrada no seio familiar (individualismo). Os objetivos da independência eram de liberdade, fim do domínio dos brancos e vingança. Tendo sido conquistadas exitosamente essas metas, não houve mais um propósito comum que convergisse em uma ampla agenda de interesse nacional.

Pode-se também observar que o fato de a economia haitiana ter ficado tanto tempo centrada no modelo de subsistência contribuiu, com base nas observações de Harrison (1985, p. 106), para uma espécie de acomodação da população quanto a sua condição e para uma maior atenção aos interesses de suas próprias famílias. Isso, em parte, explica a baixa desarticulação política e a suscetível tendência a governos ditatoriais.

No que tange à variável 'desgaste das forças armadas', vê-se que ela deriva, em boa medida, dos sucessivos golpes militares pelos quais o país passou e, também, do constate uso da coerção policial como forma de se evitar qualquer tipo de contestação a governos autoritários, sejam eles militares ou não.

Conforme visto anteriormente, sobretudo com a ditadura Duvalier, a recorrente projeção de imagem de um país fragilizado e dependente da ajuda externa passa a ser 
constantemente utilizada e, aparentemente, apenas para garantir e justificar o fácil acesso a recursos que garantissem a manutenção da elite decisória no poder.

Assim, finda essa breve reflexão sobre o panorama do ambiente psicológico haitiano, em especial do prisma atitudinal, faz-se, adiante, uma análise de discursos presidenciais amostrais $^{23}$ a fim de que possamos verificar se os elementos cognitivos identificados anteriormente estão presentes (enquanto imagens socialmente construídas) nos discursos dos chefes de Estado e, também, nas ações adotadas pela MINUSTAH.

Dessa forma, esperamos contribuir para o melhor entendimento das possíveis conexões existentes entre o quadro de instabilidade política no Haiti e as ações tomadas pela MINUSTAH vis-à-vis as projeções das imagens feitas pelas elites decisórias.

\section{As imagens Projetadas a partir da MINUSTAH: do mandato de Boniface Alexandre (2004-2006) ao governo de Michel Joseph Martelly (2011-2016)}

$\mathrm{Na}$ teoria cognitiva o uso de imagens é um importante instrumento na medida em que representa a percepção do ambiente operacional por parte das elites decisórias que atuam em um dado cenário.

Segundo Herz (1994, p. 79), os estudos que envolvem a teoria cognitiva se propõem a trabalhar com contrastes entre a realidade objetiva e as imagens projetadas para, assim, apontar elementos capazes influenciar as estratégias de ação. Em nosso estudo de caso, com a presença da MINUSTAH no Haiti há a projeção de imagens por parte de duas unidades ontológicas principais: o Estado haitiano, na figura de seus mandatários, e a Organização das Nações Unidas.

Iniciamos, destarte, essa análise com Boniface Alexandre que assumiu o comando do Haiti no dia 29 de fevereiro de 2014 após a saída de Aristide. Em seu governo, a autoimagem haitiana enxergada e projetada foi a de um país desestabilizado politicamente e dependente da ajuda externa para se reerguer e se manter. Tal percepção é clara em seu discurso proferido em 22 de abril de 2004, endereçado a doadores internacionais, quando disse que:

\footnotetext{
${ }^{23}$ De acordo com a Teoria Cognitiva, no plano internacional, uma interessante ferramenta de identificação das imagens projetadas pelas elites decisórias é a análise de discursos dos atores envolvidos. Aqui não serão observados os discursos dos Primeiros-Ministros, pois, conforme a Constituição haitiana (2012), o Primeiroministro é escolhido pelo Presidente e aprovado pela Assembleia Nacional. Portanto, nesse sentido, o mesmo tende a ter orientação política próxima à do presidente. Ainda, de acordo com a Constituição haitiana (2012), cabe ao Chefe de Estado (Presidente) dar as linhas estratégicas e operacionais do Estado, que é o que nos interessa neste artigo. Por fim, para manter a coesão textual, os autores fizeram tradução livre dos textos originalmente publicados nas línguas francesa e inglesa.
} 
Nos últimos dezoito anos, o Haiti está lutando em uma transição política sem fim. Os governos têm sido muito semelhantes; as eleições são contestadas; a assistência internacional está mais direcionada para as ONGs; os investidores haitianos e estrangeiros procuram um país mais estável politicamente; o desemprego está aumentando; os jovens estão à deriva; os homens e mulheres de negócios estão preocupados; o poder de compra diminui; e a pobreza está em pleno andamento. O desespero é geral! (Boniface Alexandre, 2004, p. 2).

Foi utilizando-se dessa percepção de fraqueza estatal que Boniface Alexandre projeta a imagem do Haiti como um país em processo de reconstrução ante o fim da transição democrática pelo qual vem passando ao longo de 18 anos.

O Haiti, em seu governo, deixa claro que quer entrar no jogo do cenário internacional, com eleições, justiça e renascimento da vida econômica e social. O fragmento do discurso de Boniface aos doadores internacionais evidencia isso, conforme a citação abaixo:

O foco dessa transição é a realização de eleições gerais no país em 2005. A organização das mesmas deve ser acompanhada por dois grandes objetivos: a luta contra a insegurança com o respaldo da justiça e o renascimento da vida econômica e social. (Boniface Alexandre, 2004, p.2).

Dadas as imagens propagadas pelo governo haitiano, a ONU, dando continuidade em seu trabalho da Força Interina Multinacional, lança a MINUSTAH e, assim, propõe um plano de estabilização do país em três áreas, todas elas com a participação de componentes civis e militares: segurança e estabilização do ambiente, reforma política e Direitos Humanos.

Mais precisamente a MINUSTAH buscou: (1) Apoiar um Governo de Transição para garantir um ambiente seguro e estável; (2) Monitorar o processo de reestruturação e reforma da Polícia Nacional do Haiti; (3) Ajudar com o desarmamento, desmobilização e reintegração (DDR); (4) Auxiliar com a restauração e manutenção do Estado de direito, da segurança pública e da ordem pública no Haiti; (5) Proteger o quadro pessoal das Nações Unidas, as instalações e equipamentos e civis sob ameaça iminente de violência física; (6) Apoiar os processos constitucionais e políticos do país auxiliando na organização, acompanhamento e realização de eleições municipais, parlamentares e presidenciais livres e justas; (7) Fornecer suporte a promoção e proteção dos direitos humanos; e (8) Apresentar relatórios sobre a situação dos direitos humanos no país.

Dessa forma, a projeção da ONU e de seus parceiros no processo de estabilização do Haiti é de um o país democrático, estabilizado, com uma polícia reformada e de respeito aos Direitos Humanos.

Comparando as duas projeções iniciais, temos que a ONU atendeu ao pedido do Presidente Boniface e forneceu o suporte necessário conforme era esperado. 
A ONU projetou a questão da democracia, vista pelo apoio político e às eleições, e de segurança, como o mandato bem demonstra. No entanto, ao invés de projetar uma imagem econômica e mais desenvolvimentista, optou por uma agenda em prol dos Direitos Humanos como prioridade para o Haiti.

É somente após quase um ano de atuação no Haiti que a MINUSTAH passa a incluir a questão econômica e de desenvolvimento, de forma ainda tímida, tal qual observado no discurso do Presidente do Conselho de Segurança ${ }^{24}$ em janeiro de 2005, com base no fragmento a seguir:

O Conselho de Segurança reconhece a necessidade da MINUSTAH, de outros órgãos do sistema da ONU, das instituições financeiras internacionais e dos Estados-Membros para ajudar o governo de transição na preparação e implementação de projetos de desenvolvimento no Haiti, bem como projetos de impacto rápido. O Conselho reitera a necessidade de ajudar o Governo de Transição no estabelecimento de uma estratégia de desenvolvimento em longo prazo. (Security Council, 2005, p. 1).

No dia 19 de setembro de 2005, Boniface Alexandre se dirige a 60ª Sessão Ordinária da Assembleia Geral das Nações Unidas para reforçar seu desejo de reconstrução do país e agradecer o trabalho da MINUSTAH e a solidariedade internacional que o Haiti tem recebido. $\mathrm{Na}$ ocasião, quanto à pauta desenvolvimentista e econômica, o mesmo cita alguns projetos propostos para o Haiti e para os países em desenvolvimento quanto a mecanismos de financiamento internacional, como o projeto da Grã-Bretanha de facilitação de empréstimos no mercado financeiro para aumentar a assistência aos países mais pobres, especialmente na luta contra a AIDS.

Dada essa discussão no âmbito da ONU, Boniface Alexandre deixou clara sua divergência quanto à maneira que se enxerga a solução para a questão de financiamento de projetos em países mais pobres, como o Haiti. Para ele, esses esforços podem não atingir seus objetivos, por manter os países pobres vinculados a dívidas internacionais "impagáveis".

Ele ainda propõe que as mesmas sejam perdoadas. O fragmento abaixo ilustra esse posicionamento haitiano quanto aos atuais programas de financiamento internacionais:

No entanto, estes esforços não podem alcançar seus objetivos, sem uma solução global para as dívidas dos países do sul. Esta solução irá fazer uma contribuição positiva para a segurança internacional, não só considerando o cancelamento total das dívidas dos países menos desenvolvidos, mas também em ajudá-los a superar o problema, facilitando o seu desenvolvimento (Boniface Alexandre, 2005).

\footnotetext{
${ }^{24}$ A presidência do Conselho de Segurança das Nações Unidas é exercida de maneira alternada, mensalmente, por cada uma das 15 nações que o compõe, na figura de seu embaixador na organização.
} 
Por fim, de acordo com discurso proferido na ocasião da celebração da independência haitiana em 1 de janeiro de 2006, o Governo Provisório entrega para o governo eleito um Haiti com avanços nas seguintes áreas: (1) Política físcal e orçamental de aumento das receitas, (2) racionalização das despesas públicas e controle do déficit orçamental; (3) fortalecimento das administrações fiscais e aduaneiras; (4) luta contra a fraude; (5) financiamento de 98 projetos de melhorias das condições de vida; (6) programa de descentralização administrativa; (7) projetos de infraestrutura rodoviários, gerando muitos empregos; (8) modernização de muitos hospitais; (9) campanhas governamentais de combate a AIDS; (10) reforma de algumas instalações desportivas; e (11) organização de eleições com o auxílio da ONU.

Após quatro remarcações, em 7 de fevereiro de 2006, ocorrem as tão aguardadas eleições presidenciais no Haiti, com a vitória de René Préval. Ressalta Lazier (2006, p.6) que elas ocorreram em um ambiente político conturbado propiciado pelo: (1) suicídio do general brasileiro, Urano Teixeira da Mata Bacelar, que comandava a MINUSTAH (embora não haja um consenso se de fato foi suicídio); (2) proliferação de sequestros; (3) acusações de membros das tropas de paz da ONU de excesso de violência; (4) greve geral pelas insatisfações de empresários e da população com o trabalho da MINUSTAH; (5) demissão da Suprema Corte Haitiana pelo Primeiro-Ministro interino por autorizar a participação nas eleições de Dumarsais Simeus, empresário com dupla cidadania; e (6) precariedade policial e judicial.

É importante destacar que René Préval já havia sido presidente do Haiti de 1996 a 2001 e Primeiro-Ministro em 1991. O mesmo, ainda, era seguidor de Aristide, o que gerou inicialmente um temor quanto a sua posse, uma vez que as elites do país se posicionavam fortemente contra o governo de Aristide.

Ainda que com o cenário instável, Préval conseguiu cumprir seu mandato de 5 anos. Em seu primeiro discurso no Conselho de Segurança da ONU, em março de 2006, ainda que sua posse estivesse prevista para maio do mesmo ano, Préval reforçou a imagem projetada por Boniface Alexandre de um país marginalizado e dependente do apoio internacional, além da projeção do interesse nacional pela reconstrução do Estado de Direito.

Apesar da convergência com esta imagem projetada por seu antecessor, Préval também priorizou, com base em entrevista concedida à ICI Radio Canadá, em 2006, outros aspectos conjunturais que reforçaram essa percepção como: restabelecer e solidificar as 
instituições democráticas, necessidade de fornecimento de comida e emprego ao povo haitiano e busca por investimentos privados.

Um aspecto amplamente observado é que, embora as agendas tivessem pesos diferenciados nas resoluções da MINUSTAH em relação à escala de prioridades do governo, a ONU mostrou-se aberta, na elaboração de suas ações, à incorporação das demandas presidenciais tal qual externadas nos discursos, sobretudo, quando referendavam a realidade objetiva dos fatos. Uma evidência disso está na Resolução 1743 (2007, p.2) em que a ONU destaca a necessidade da rápida implementação de projetos que gerem empregos e supram necessidades básicas da população. Assim:

[a ONU] Sublinhando a necessidade de implementação rápida de projetos de mão-de-obra intensiva que ajudem a criar empregos e oferecer serviços sociais básicos e enfatizando a importância de projetos de impacto rápido na fase pós-eleitoral, Reconhecendo o louvável trabalho realizado pelas autoridades haitianas e MINUSTAH para responder às necessidades das pessoas afetadas pelo desastre e acolher futuras ações coordenadas a este respeito(...) (Security Council, 2007, p.2),

A ONU, ademais, incorporou nas suas resoluções do mandato o primeiro objetivo destacado anteriormente por Préval de fornecer emprego para o povo haitiano. No entanto, ainda com base na Resolução 1743 (2007, p.2), ao enfatizar a responsabilidade política e civil do país por mais de uma vez, a imagem projetada do Haiti - de fragilidade e dependência de apoio internacional - talvez esteja sendo percebida pelo Conselho de Segurança como um possível acomodamento ante o apoio oferecido pela instituição internacional:

4. [a ONU] Reconhece a propriedade e responsabilidade primária do Governo do Haiti sobre todos os aspectos de estabilização do país e boa governança e reconhece o papel da MINUSTAH em apoiar os esforços do governo a este respeito, e exorta o Governo do Haiti para continuar a aproveitar ao máximo apoio internacional para aumentar a sua capacidade (Security Council, 2007, p.2).

Esse temor do Conselho de Segurança ao assistencialismo que a MINUSTAH vinha gerando no Haiti e, por consequência, na perpetuação do quadro de dependência externa em relação a ONU, encontra respaldo no fato de que o presidente Préval, além de seguir o posicionamento de seu antecessor quanto ao papel central da ajuda internacional para a reestruturação do Haiti, na ocasião da $62^{\mathrm{a}}$ Assembleia Geral da ONU, intensificou de forma dramática a imagem de país marginalizado, enfatizando a importância da solidariedade internacional, da abertura de mercados e transferência tecnológica de países desenvolvidos em prol de conseguir a renovação do mandato da MINUSTAH por mais 12 meses. O fragmento abaixo evidencia essa colocação: 
Senhor Presidente, falo aqui em nome de um povo que sofre há 200 anos com a privação material de todos os tipos, vulnerabilidade a riscos naturais e desastres, dificuldade de acesso aos cuidados de saúde e educação, mortes de centenas de milhares de crianças devido a desnutrição e uma população muito jovem ( $65 \%$ menos de 25 anos) privada de oportunidades reais de emprego.

Eu falo em nome de um povo que parece estar esvaziando-se quando seus executivos mais competentes abandonam um diário difícil para aumentar o desempenho de outras administrações ou outras empresas no Canadá, na França e nos Estados Unidos, ou quando seus filhos, mulheres grávidas e anciãos, cansados de viver uma vida que não lhes parece melhorar saem em barcos improvisados, em busca de uma vida melhor sob os outros céus.

$\mathrm{Eu}$ falo em nome de um estado que seus vizinhos, mesmo os mais poderosos, às vezes o apresentam como uma ameaça para a segurança da região, porque o Haiti também aparece frequentemente na agenda da Assembleia Geral ou do Conselho de Segurança das Nações Unidas com um grande contingente de problemas de insegurança ou turbulência política.

Eu falo em nome de um país que é muitas vezes descrito como um Estado Falido porque tem dificuldade operar suas instituições e organizar um espaço de vida adequado para todos os seus cidadãos ; porque, infelizmente, este estado é muitas vezes muito ocupado com uma guerra sem um futuro contra seus próprios filhos.

Resulta desta observação que devemos adquirir uma nova cultura de solidariedade internacional baseada em uma abordagem global e coordenada em que a luta contra a pobreza acompanha o desenvolvimento sustentável; uma abordagem em que a ajuda ao desenvolvimento e a luta contra a insegurança são contrárias aos esforços dos países mais desenvolvidos para abrir seus mercados, encorajar os fluxos de investimento direto estrangeiro e as transferências de tecnologia e apoiar o setor privado e iniciativas empresariais; uma abordagem global em que os ricos e os pobres percebem que são co-proprietários desse planeta e que seu destino está em nossas mãos. (Préval, 2007)

Préval, ainda no supracitado discurso, enfatiza os avanços do seu governo em conjunto com a MINUSTAH, tentando projetar uma imagem de progresso em meio ao caos ${ }^{25}$. Segundo ele (2007), houve avanços quanto ao desmantelamento crescente das gangues e milícias, na redução da inflação e crescimento moderado do PIB, na governança do país, na consolidação das estruturas de Estado, em reformas legais, no constante combate à corrupção e em melhoras na estrutura da Polícia Haitiana.

Em 2008, o Haiti é atingido por furacões que comprometem ainda mais sua frágil infraestrutura e, concomitantemente, agrava os diversos problemas do país. Diante desse acontecimento, Préval vai à $64^{\mathrm{a}}$ Assembleia Geral da ONU e faz duras críticas ao sistema internacional e à atuação da $\mathrm{ONU}$, transparecendo certo desespero, conforme citado em seu discurso abaixo:

Parece, mesmo, que, além de muitas crises de todos os tipos (alimentar, energética, financeira, etc.) que já impõem um pesado tributo sobre o nosso povo, alguns de nós têm agora de se

\footnotetext{
${ }^{25}$ De fato, o Haiti apresentou uma melhora significativa no período. Segundo Heine e Thompson (2011, p.6), a situação da insegurança melhorou, com a redução dos sequestros, e houve crescimento econômico continuado, sendo um dos dois países da América que tiveram elevações no crescimento, em 2009. Além disso, os autores destacaram que Préval, até então, nunca tivera seu nome associado a escândalos de corrupção como aconteceram seus antecessores. Préval teve, contudo, que enfrentar grandes desafios como o aumento generalizado nos preços de commodities, sobretudo, alimentos, e a queda do Primeiro-Ministro Jacques-Edouard Alexis.
} 
acostumar a choques recorrentes que vêm de desastres naturais. Devemos, em cada tiro, reconstruir a mesma infraestrutura que foi destruída; devemos restaurar a mesma capacidade produtiva que foram varridas por ciclones e inundações. A falta de recursos faz com que o processo de reconstrução não seja iniciado no tempo e você tem que se preparar para o retorno do desastre antes mesmo de que as comunidades sejam capazes de se recuperar de desastres anteriores. Era, aparentemente, para este novo ciclo de vida que os países vulneráveis, como o nosso, devem ser preparados. Com meios insuficientes. Esta não é uma coincidência. É a consequência direta do desenvolvimento e modelo de governança que as nações conhecidas como poderosas impuseram ao resto do mundo para várias modelo seculares. (Préval, 2009).

Tal colocação é interessante do ponto de vista da abordagem cognitiva pois indica que em casos de acontecimentos inesperados e urgentes, o tomador de decisão pode tender a projetar uma imagem não condizente com a realidade.

Isso fica evidente, também, a partir do fato de que, visando atrair cada vez mais ajuda de seus pares, Préval passa até mesmo a tentar projetar uma imagem do país que diverge dos elementos históricos constitutivos das imagens do Haiti no que concerne a questão da organização social centrada no seio familiar (individualismo). O trecho do discurso, a seguir, revela bem esse aspecto:

Os haitianos, como muitos outros povos do Sul, são um povo laborioso, engenhoso e empreendedor; dotado de uma grande resiliência forjada na gestão do problema cotidiano e capaz de explorar o limite extremo e otimizar o menor recurso colocado à sua disposição. Nosso povo está ansioso para mobilizar esse potencial e essa capacidade de seguir o caminho do desenvolvimento sustentável. O desenvolvimento de nossos países é, portanto, uma tarefa possível. No entanto, todos os esforços provavelmente serão ineficazes se não conseguirmos um novo paradigma de cooperação internacional. Um novo paradigma que nos obriga a ultrapassar a lógica da ajuda humanitária e reconhece a capacidade dos pobres de fazer negócios e gerar riqueza através dos meios e oportunidades disponíveis para desenvolver suas capacidades produtivo. Sem uma visão tão nova, romper com a cultura da ajuda humanitária perpétua, paz e estabilidade só serão conquistas precárias e fugazes (Préval, 2009)

Esse acontecimento (dos furacões) também foi crucial para catalisar choque de percepções entre as imagens projetadas pelo governo no período e a MINUSTAH. Isso é perceptível na recorrente importância atribuída à variável Direitos Humanos em várias resoluções. Exemplo é a Resolução 1840 por meio da qual o Conselho de Segurança, referente aos casos de abusos sistemáticos contra crianças e de estupros de mulheres, determinou tolerância zero:

20. Reafirma o mandato da MINUSTAH em matéria de direitos humanos e exorta as autoridades haitianas a prosseguirem os seus esforços para promover e proteger os direitos humanos e exorta a MINUSTAH a continuar a proporcionar formação em direitos humanos à PNH e outras instituições, incluindo os serviços de prisão; 21. Condena firmemente as violações graves contra crianças afetadas por estupro e outros abusos sexuais de meninas, e 22. Solicita ao Secretário-Geral que continue a tomar todas as medidas necessárias para garantir o pleno cumprimento da política de tolerância zero das Nações Unidas em matéria de exploração e abuso sexual e manter o Conselho informado (Security Council, 2008, p. 5). 
Essa observância da ONU entra em choque, portanto, com o discurso de Préval na $64^{\mathrm{a}}$ Assembleia das Nações Unidas, onde ele claramente tentou vender uma imagem de um Haiti que respeita os Direitos Humanos e possui uma população altamente amigável. O fragmento abaixo demonstra essa tentativa:

Nos últimos três anos, apesar do impacto negativo de muitas crises internacionais sobre nossa economia, o progresso significativo foi feito, particularmente na segurança, no respeito dos direitos humanos, no clima de investimento em eliminação da corrupção, e o estabelecimento de uma sociedade amigável, onde o diálogo é central, apoiado e retransmitido por uma imprensa totalmente livre e independente (Préval, 2009).

É interessante essa análise porque pela primeira vez, o termo Direitos Humanos aparece de forma clara no discurso presidencial de Préval como instrumento para vender a ideia de que no Haiti não existe tal problema. Essa imagem projetada pelo governo haitiano vai na contramão do componente histórico do prisma atitudinal desenhado pelo país de violação sistemática dos Direitos Humanos e é incorporado pela ONU no mandato da MINUSTAH.

Provavelmente o intento de Préval, diante da crescente atenção dedicada pelas Nações Unidas à questão dos Direitos Humanos em suas resoluções, tenha sido tentar fazer com que a pauta desenvolvimentista, mediante financiamento externo, crescesse em relevância em detrimento dessa agenda.

De qualquer forma, a Resolução 1892, menciona os avanços conseguidos pelo governo haitiano como eleições para senadores e adoção de uma reforma constitucional. Ainda assim, o Conselho de Segurança da ONU (2009, p. 4) permaneceu enfatizando que havia muito a se fazer em termos de governança, sistema prisional e judiciário no Haiti.

O ano de 2010 chega com mais um problema, o terremoto de magnitude de 7 graus na escala Richter que agrava a situação do país. O terremoto faz com que a MINUSTAH reforçasse seu pessoal. Além disso, houve um escândalo envolvendo a ONU, uma vez que o Haiti passou por um surto de cólera supostamente trazido por capacetes azuis nepaleses.

A partir disso, ainda na citada conferência, Préval projeta uma nova imagem: a de um povo solidário, corajoso e heroico que renasceria da tragédia com um plano de uma sociedade mais igualitária e inclusiva. Além disso, tenta vender a percepção de que a situação vista pela fuga de haitianos é uma ficção, tal como observado no fragmento do discurso abaixo:

Eu não posso esquecer a coragem, a solidariedade e heroísmo demonstrado pelos próprios haitianos. O exemplo de amor, compromisso, auto sacrifício, por vezes, vem dos mais pobres que não hesitou um segundo para colocar suas próprias vidas em risco a correr em auxílio de 
outro haitiano, que eles nem sequer conhecem. A atenção, solidariedade e mobilização da diáspora têm mostrado que a distinção entre ser haitiano e haitiana dentro e vida haitiano e haitiana no exterior é uma ficção administrativa. (Préval, 2010).

É, assim, a partir desse novo cenário de desastres naturais e perda dos avanços alcançados, que se acentuam cada vez mais as divergências quanto às projeções da hierarquia de agendas e um distanciamento por parte do presidente da real situação do país. No entanto, apesar dos reveses listados, Heine e Thompson (2011,p.7) ressaltam que investidores internacionais valorizaram o fato de o governo de Préval ter sido democraticamente eleito e ter se mantido. Isso ajuda a compreender o porquê do Haiti ter conseguido mobilizar esforços conjuntos de países, setor privado, organizações internacionais e ONGs para a sua reconstrução no pós-terremoto.

Com o fim do mandato de Préval, Michel Joseph Martelly, um famoso músico haitiano, é eleito presidente em 4 de abril de 2011. As projeções de Martelly, para seu governo, exaltavam claramente o orgulho haitiano de seu processo de independência, e se centrava na imagem de reconstrução.

Quanto ao apoio internacional, passa a citá-lo, não para receber comida e recursos, como os seus antecessores demandavam, mas para pedir investimento estrangeiro e abrir a economia do Haiti. O trecho abaixo de seu discurso de posse, assim, evidência:

\begin{abstract}
O Reverendo Martin Luther King teve um sonho para os Estados Unidos. Eu também tive um sonho para o Haiti e seu povo. Eu sonhei com o Haiti, onde, após o mandato de cinco anos, a grande maioria dos filhos do Haiti aprenderá a ler e escrever. Sonhei com um Haiti, onde além da forte resiliência das pessoas, seremos capazes de criar ou estabelecer as bases para um ambiente menos degradado e que seja mais capaz de suportar a força do furacão, a capacidade de destruição do terremoto e a ação insidiosa das chuvas no solo. Sonhei com o Haiti, onde o crescimento econômico e a sustentabilidade do processo de desenvolvimento permitirão ao povo haitiano expressar melhor sua surpreendente capacidade criativa, não só pelas artes, mas também pela ciência e pela tecnologia. Eu sonho com um Haiti forte, bonito e próspero como sonhado pelos heróis da nossa independência: Toussaint Louveture, Jean Jacques Dessalines, Henri Christophe, Alexandre Petion. Eles inspiram minha visão e minha missão. Alguns dirão que existem dificuldades aparentemente insuperáveis que enfrentam o Haiti. Mas é tudo uma questão de liderança, isto é, a capacidade de envolver nossos compatriotas para ter uma visão positiva e construtiva do futuro. Minha equipe e eu queremos influenciar positivamente o curso da história do Haiti e pôr fim ao círculo vicioso que a dominou há mais de três décadas. Nossa visão é a de um Haiti diferente do mostrado por certos meios de comunicação. Queremos mudar o Haiti para melhor e vamos mudar isso. (Martelly, 2011).
\end{abstract}

Em sua Resolução 2012, contemporânea do discurso supracitado, todavia, o Conselho de Segurança (2012, p.5) ainda não havia se manifestado quanto à provocação do presidente quanto à atração de investimentos estrangeiros para o Haiti. A ONU se restringiu a manter-se pedindo o auxílio de doadores, como já era praxe. 
Em meados de 2012, Martelly, ao se pronunciar na Assembleia Geral Haitiana, deixou claro que na definição de uma agenda de interesse nacional priorizaria fatores desenvolvimentistas para o país, vistos, não apenas na atração de investimentos estrangeiros, mas, também, na melhoria da infraestrutura e na atenção especial às potencialidades do setor de tecnologia da informação e da educação. Conforme suas palavras:

Gostaria de ver essas cinco áreas prioritárias apoiadas por 5 setores, são elas: (1) A construção e infraestrutura; (2) A contribuição de capital para o sector das PME; (3) A Tecnologia da Informação e Comunicação (TIC) sabendo que a tecnologia é o motor da competitividade; (4)Educação e formação para atender a demanda das áreas prioritárias para habilidades específicas; (5)Um ambiente de negócios favorável, obtida através de uma parceria públicoprivada (PPP), através de uma reforma política pública e a promoção sistemática de empreendedorismo. (Martelly, 2012).

Ele ainda enfatizou, nessa ocasião, a importância de se investir na agricultura para a imagem de progresso em seu governo, demonstrando não ignorar o passado, ligado as fazendas de subsistência do Haiti:

\begin{abstract}
Penso particularmente no mundo rural (...) Ao governo, reitero a minha demanda. Ao parlamento, busco a assistência. Da população, sua participação ativa. O Estado deve comprometer-se a investimentos maciços em áreas rurais para preservar a infraestrutura existente, criar novas e prestar serviços aos agricultores que lhes permitam gerar ganhos de produtividade substanciais. Mas não devemos esquecer que o camponês é agora um buscador de cidades. Puxado para fora de sua casa por políticas econômicas irresponsáveis, recusando o isolamento do assentamento disperso, desejando que seus filhos se beneficiem dos benefícios da educação, o camponês chega à cidade em busca de um ser melhor, que o seu estado atual, não pode oferecê-lo. (Martelly, 2012)
\end{abstract}

Apesar dessa disposição para com as agendas desenvolvimentistas, é importante mencionar a descrença política em torno de Martelly $^{26}$. Como ele e sua equipe careciam de experiência de gestão e política, muitos observadores ficaram preocupados com a capacidade do presidente em garantir as promessas de educação gratuita e obrigatória, geração de empregos, desenvolvimento agrícola e fortalecimento do Estado de Direito (Taft-Morales, 2015, p. 10).

Um ponto interessante no discurso de Martelly, na Assembleia Nacional, foi o reconhecimento dos elementos negativos que contribuíram para uma imagem ruim do Haiti ao longo dos anos, conforme evidenciado anteriormente:

\footnotetext{
${ }^{26}$ De fato, a gestão Martelly foi marcada por grandes impasses entre seu governo e o Legislativo haitiano. Na ocasião, devido à violação de imunidade de parlamentares, os mesmos retalharam o então Presidente, não votando suas propostas e até abrindo um inquérito sobre uma possível nacionalidade americana e a impossibilidade de exercer o cargo (Taft-Morales, 2015, p. 10).
} 
Eu nunca vou parar de insistir que a miséria e egoísmo haitiano que tem prevalecido até agora, desapareça para sempre para abrir caminho para um Haiti vibrante, dinâmico, próspero, justo e firmemente focado no futuro (Martelly, 2012).

Dessa forma, ele parece tocar no individualismo presente na gênese do povo haitiano. Martelly, ainda coloca em sua pauta o objetivo do fortalecimento das Forças de Defesa Haitianas, como o mandato da MINUSTAH vinha propondo. Assim, disse ele:

Aproveito esta oportunidade para projetar minha visão para a criação de uma nova Força de Defesa de nosso território. Ao fazê-lo, o Estado vai recuperar a sua soberania e se preparar, com apoio da MINUSTAH. A Força de Defesa vai assumir o controle do território e suas fronteiras, dar uma mão para a polícia em caso de necessidade, mas também irá intervir em caso de catástrofes naturais e, assim, cumprir sua missão constitucional. (Martelly, 2012).

Martelly, ainda, demonstrou entender o que a ONU vinha pontuando em seu mandato: de que, apesar da atuação da MINUSTAH, a responsabilidade primaria da reconstrução e desenvolvimento é do próprio Haiti. Isso é visto de maneira clara no discurso presidencial sobre o surto de cólera, onde o Presidente evocou a responsabilidade estatal e do próprio povo haitiano ao afirmar:

Recebemos muitas promessas para assistência à reconstrução, mas precisamos agir agora. É um direito de todos os haitianos e haitianos ter acesso a água potável e ter instalações sanitárias adequadas. Somente uma abordagem estratégica abrangente e gerida conjuntamente pode nos ajudar a eliminar a cólera que afetou meio milhão de haitianos e matou milhares. Assim, podemos recuperar uma população haitiana saudável, livre de cólera, dentro de uma década. Em cooperação com os nossos vizinhos na República Dominicana, podemos alcançar um futuro melhor para todos os cidadãos da Hispaniola. Hoje, peço ao nosso Ministro da Saúde que organize um encontro com nossos vizinhos na República Dominicana e nossos parceiros internacionais e locais que apoiem essa luta para determinar uma estratégia conjunta para eliminar a cólera da nossa ilha. (Martelly, 2012)

A resolução 2070 do Conselho de Segurança (2012, p 5) parece reconhecer esses avanços por parte do novo dirigente quanto às imagens projetadas e a noção de responsabilidade primária nacional. Tanto que, na referida resolução, a ONU destaca o progresso rumo ao desenvolvimento econômico e social e na ocasião da cólera, destaca também o esforço feito pelo governo para sanar o problema. ${ }^{27}$

No entanto, o Conselho de Segurança $(2012$, p.6) continua condenando e chamando a atenção do governo paras violações de Direitos Humanos, sobretudo de crianças.

\footnotetext{
${ }^{27}$ A ONU reconheceu os avanços do governo Martelly na capacitação policial e judiciária para investigar a corrupção e crimes políticos, contudo, mencionando que os níveis ainda eram altos e que o próprio Martelly foi investigado. Também criticou a politização do judiciário e da polícia nacional sob sua administração, já que a constante troca de gabinetes afetava os esforços da MINUSTAH e subjulgava essas entidades aos interesses políticos do Presidente. As prisões arbitrárias e ilegais e a perseguição de jornalistas também foram duramente criticadas pela ONU (Taft-Morales, 2015, p. 11).
} 
Ainda que com o reconhecimento, a resolução não menciona esforços em nenhuma das áreas alavancadas pelo governo como prioritária. As resoluções seguintes também não trazem grandes convergências com os discursos presidenciais. Até então a postura da ONU se manteve a mesma, ou seja, em prol de reformas na área de segurança, política e de Direitos Humanos.

Em contrapartida, o discurso presidencial revelou cada vez mais uma maior autonomia e ciência de sua responsabilidade e do papel da MINUSTAH, o que representou um progresso. Isso ficou bem claro quando, na $70^{\mathrm{a}}$ Assembleia Geral da ONU, diferentemente de seus antecessores, pela primeira não se buscou vender um Haiti que precisasse da ajuda internacional para todos os setores e, sim, um Haiti mais forte e alinhado à ação da MINUSTAH.

Permita-me mencionar a situação do meu país, a República do Haiti. Em 9 de agosto, um passo importante foi dado na consolidação da democracia. Um independente Conselho Eleitoral, escolhido pela Sociedade Civil, iniciou o processo eleitoral que deverá conduzir até o final deste ano, a realização de eleições presidenciais, legislativas, municipais e territorial. No seu relatório da MINUSTAH ao Conselho de Segurança, o Secretário-Geral observou que a eleição foi essencial para a consolidação da democracia e do Estado de direito e a promoção do desenvolvimento, desde necessário para melhorar as condições de vida da população haitiana e a realização de uma estabilidade duradoura. Estou feliz de informar a esta Assembleia que o país está no caminho certo. O povo haitiano demonstrou maturidade política e sua capacidade de ter o controle de seu destino. Aqui eu gostaria de expressar minha profunda gratidão a todos os parceiros de cooperação no Haiti e as Nações Unidas. (Martelly, 2015)

Martelly entregou seu cargo em fevereiro de 2016, ao fim de seu mandato constitucional de cinco anos. Ainda que o Haiti possa aparentar ter tido grandes avanços, como externado nos discursos presidenciais e nas resoluções da ONU, Martelly passou o poder para um governo provisório, já que as eleições foram suspensas por suspeitas de fraude, mergulhando o país em outra onde de desestabilização política. Somente em novembro de 2016, um novo presidente foi eleito ${ }^{28}$.

Assim, levando-se em consideração as imagens construídas ao longo da história haitiana e projetadas durante a MINUSTAH cabe-nos um derradeiro esforço em mostrar uma síntese do processo de aderência destas por parte de cada um dos governos haitianos vis-à-vis a missão à MINUSTAH:

\footnotetext{
${ }^{28} \mathrm{O}$ candidato vitorioso foi o empresário Jovenel Moise, apoiado pelo ex-presidente Martelly. Até o fechamento dessa pesquisa, não havia dados suficientes para uma análise profunda do papel das imagens projetadas no governo Moise.
} 
Quadro 2 - Quadro das imagens projetadas ao longo da MINUSTAH (2004-2016) ${ }^{29}$

\begin{tabular}{|l|c|c|c|c|}
\hline \multicolumn{1}{|c|}{ IMAGENS } & $1^{*}$ & $2^{*}$ & $3^{*}$ & $4^{*}$ \\
\hline $\begin{array}{l}\text { País marginalizado } \\
\text { e dependente da } \\
\text { ajuda externa }\end{array}$ & SIM & SIM & NÃO & SIM \\
\hline Reconstrução & SIM & SIM & SIM & SIM \\
\hline $\begin{array}{l}\text { Esforços para a } \\
\text { consolidação da } \\
\text { democracia no país }\end{array}$ & SIM & SIM & SIM & SIM \\
\hline Progresso & SIM & SIM & SIM & SIM \\
\hline $\begin{array}{l}\text { Respeito aos } \\
\text { Direitos Humanos }\end{array}$ & NÃO & SIM & NÃO & NÃO \\
\hline $\begin{array}{l}\text { Povo solidário e } \\
\text { forte }\end{array}$ & NÃO & SIM & SIM & NÃO \\
\hline
\end{tabular}

Analisando o quadro, nota-se um consenso dos atores quanto às a) projeções de reconstrução, b) país em processo de consolidação da democracia e c) o progresso. É importante destacar, no que tange ao progresso, que o mesmo refere-se aos passos rumo à estabilização, fortalecimento político e desenvolvimento econômico e social do país.

No que concerne à imagem de um país marginalizado e dependente da ajuda internacional, tem-se que essa projeção só não é vista em Martelly. Como previamente dito, com ele surgiu a retórica da imagem de um povo forte e solidário, mas que precisa se aprimorar e assumir responsabilidades no processo de reconstrução. Dessa forma, ele apenas solicita o apoio da sociedade internacional para a atração de investimentos externos.

Já as imagens que dizem respeito aos Direitos Humanos e de um povo solidário e forte foram ressaltadas, sobretudo, por René Préval. Em contrapartida, a percepção que a ONU apresentou do país foi divergente, uma vez que foram feitas diversas menções aos casos de estupro e violência em suas resoluções.

Quanto aos demais presidentes, o assunto Direitos Humanos não foi tratado diretamente por nenhum deles. Michel Martelly também foi outro presidente que utilizou da imagem de um país solidário e forte para conseguir comoção interna e internacional para o seu discurso.

A imagem de reconstrução, por sua vez, é interessante de ser observada cuidadosamente, pois foi consenso entre todos os atores envolvidos. No entanto, conforme

\footnotetext{
${ }^{29}$ A título de legenda para a tabela, foi utilizado o termo "SIM", para evidenciar a presença de cada imagem nos discursos presidenciais e/ou da MINUSTAH. Em contrapartida, o termo "NÃO” foi utilizado para representar a não incorporação de uma imagem em cada discurso.
} 
visto, há divergência quanto ao que se definiu como sendo prioridade. Nesse sentido, para a ONU, as prioridades foram, em ordem de importância: a) Segurança, b) reforma política e c) Direitos Humanos. Já sob o ponto de vista dos presidentes haitianos, foi importante priorizar o desenvolvimento econômico e social.

Assim, apresentada a síntese das imagens construídas, o quadro seguinte demonstra a convergência entre os elementos históricos e societais, constantes no prisma atitudinal, com as projeções de cada ator:

Quadro 3 - Convergência entre os elementos do prisma atitudinal com as imagens identificadas ao longo da MINUSTAH (2004-2016) por cada ator destacado ${ }^{30}$

\begin{tabular}{|c|c|c|c|c|}
\hline $\begin{array}{c}\text { ELEMENTOS DO } \\
\text { PRISMA } \\
\text { ATITUDINAL }\end{array}$ & $1 *$ & $2 *$ & $3 *$ & $4^{*}$ \\
\hline $\begin{array}{l}\text { Raiz religiosa } \\
\text { fundamentada na } \\
\text { prática do Vodu }\end{array}$ & NÃO & NÃO & NÃO & NÃO \\
\hline $\begin{array}{c}\text { Desavenças e } \\
\text { desigualdades } \\
\text { raciais entre negros } \\
\text { e mulatos }\end{array}$ & NÃO & NÃO & NÃO & NÃO \\
\hline $\begin{array}{c}\text { Dificuldade de } \\
\text { definição de uma } \\
\text { agenda de interesse } \\
\text { nacional }\end{array}$ & SIM & SIM & SIM & NÃO \\
\hline $\begin{array}{l}\text { Organização social } \\
\text { centrada no seio } \\
\text { familiar } \\
\text { (individualismo) }\end{array}$ & NÃO & SIM & SIM & NÃO \\
\hline $\begin{array}{c}\text { Desarticulação } \\
\text { política }\end{array}$ & SIM & SIM & SIM & SIM \\
\hline Corrupção & NÃO & SIM & NÃO & NÃO \\
\hline $\begin{array}{c}\text { Violação } \\
\text { sistemática dos } \\
\text { Direitos Humanos }\end{array}$ & NÃO & SIM & NÃO & SIM \\
\hline $\begin{array}{c}\text { Desgaste das } \\
\text { Forças Armadas } \\
\text { haitianas, e por } \\
\text { consequência, das } \\
\text { instituições de } \\
\text { segurança } \\
\text { nacionais }\end{array}$ & SIM & SIM & SIM & SIM \\
\hline $\begin{array}{c}\text { Autoritarismo } \\
\text { Governamental }\end{array}$ & SIM & SIM & SIM & SIM \\
\hline
\end{tabular}

\footnotetext{
${ }^{30}$ A título de esclarecimento, foi utilizado o termo "SIM" para sinalizar a incorporação do elemento do prisma atitudinal nos discursos de cada presidente e no mandato da MINUSTAH. Em contrapartida, o termo "NÃO" foi utilizado para representar a não observância dos elementos do prisma atitudinal pelos atores destacados.
} 


\begin{tabular}{|c|c|c|c|c|}
\hline $\begin{array}{c}\text { Presença } \\
\text { substancial nos } \\
\text { discursos de um } \\
\text { país pobre e } \\
\text { dependente da } \\
\text { ajuda externa. }\end{array}$ & SIM & SIM & NÃO & SIM \\
\hline $\begin{array}{c}\text { Tentativas } \\
\text { fracassadas de } \\
\text { estabelecimento de } \\
\text { instituições } \\
\text { democráticas } \\
\end{array}$ & SIM & SIM & NÃO & SIM \\
\hline $\begin{array}{l}\text { Percepção da } \\
\text { necessidade de } \\
\text { reforma das } \\
\text { instituições } \\
\text { políticas, } \\
\text { econômicas e de } \\
\text { segurança do país. }\end{array}$ & SIM & SIM & SIM & SIM \\
\hline
\end{tabular}

*Legenda: 1 - Boniface Alexandre; 2 - René Préval; 3 - Michel Joseph Martelly; 4 MINUSTAH

Fonte: Elaborado pelos autores (2016).

Observando os componentes do prisma atitudinal elencados no quadro, observa-se que houve a incorporação total nas imagens projetadas, por todos os atores analisados, dos elementos: desarticulação política, autoritarismo governamental, desgaste das Forças Armadas haitianas, e por consequência, das instituições de segurança nacionais e a noção da necessidade de reforma das instituições políticas, econômicas e de segurança do Haiti.

Dessa forma, a percepção desses elementos por todos os atores envolvidos viabilizaram a presença da MINUSTAH e do seu mandato. As imagens resultantes da incorporação dos elementos identificados anteriormente foram: esforços para a consolidação da democracia no país e reconstrução.

As tentativas fracassadas de estabelecimento de instituições democráticas é outro elemento presente no discurso dos agentes, ainda que não diretamente no caso de Michel Martelly, e com grandes reflexos nas imagens projetadas por todos os atores dado o background do ambiente operacional anterior a MINUSTAH. Esses elementos foram incorporados, portanto, nas imagens de: reconstrução, país marginalizado e dependente da ajuda externa e esforços para a consolidação da democracia no país.

Ainda sim, conforme visto, apesar de enxergar o Haiti como um Estado frágil, a ONU, com o tempo, passa a deixar claro o papel a ser desempenhado pelos governos haitianos e pelo povo para que o país se desenvolva. Nesse cenário, apenas Martelly parece incorporar essa nova percepção ao seu discurso. 
A dificuldade de definição de uma agenda de interesse nacional, por sua vez, foi absorvida por parte dos presidentes do Haiti durante a MINUSTAH, sobretudo por meio das imagens de reconstrução e tentativas de consolidação da democracia no país. Nesse sentido, a presença desse elemento foi tão marcante no processo de reconstrução que permitiu que as agendas propostas pela ONU divergissem das percepções do país quanto à prioridade das mesmas.

Ainda, é interessante ressaltar que essas questões das agendas seguem, a partir do governo de René Préval, a mesma escala de prioridade com relação à gestão posterior de Martelly. No mandato de Boniface Alexandre, ele tendeu a se aproximar da projeção da ONU em termos de prioridade dado o colapso do setor de segurança no país e que culminou na sua posse como presidente Interino com a renúncia de Aristide.

No que tange à corrupção, temos um aspecto interessante: René Préval é o único ator a tratar do assunto, mas de maneira superficial e, sem incorporá-lo a nenhuma de suas projeções.

Outro elemento controverso é a questão da violação sistemática dos Direitos Humanos. É nítido que é com essa agenda que as grandes divergências quanto a ONU aconteceram, de forma mais acentuada no governo de Préval. Os demais governos foram omissos sobre o assunto.

De acordo com o que foi colocado ao longo do artigo, percebe-se, ainda, que, no que diz respeito ao componente do prisma atitudinal - 'organização social centrada no seio familiar (individualismo)' - esse elemento só encontra espaço nos discursos de Préval e Martelly. Préval a absorve de maneira divergente ao prisma, tentando projetar para o cenário internacional a imagem de que o povo haitiano é solidário e forte.

No governo de Martelly, a questão do individualismo volta a aparecer, mas em conformidade com a realidade histórica e atual do país. Martelly, assim, assume os problemas advindos desse elemento e reprojeta as imagens de progresso e de um povo solidário e forte capaz de modificar essa realidade, vinculado uma a outra. Portanto, para o progresso continuar seria necessário combater esse aspecto do prisma "individualismo".

Por fim, dois componentes societais do prisma atitudinal de bastante relevância ao longo de toda a análise histórica desse artigo - raiz religiosa fundamentada na prática do Vodu e desavenças e desigualdades raciais entre negros e mulatos - não foram levados em consideração por nenhum ator. Tal ponto é sintomático, pois reflete que a incorporação de 
elementos sociais/societais, tão necessárias para a superação dos problemas haitianos, aparentam ocupar importância secundária neste complexo cenário.

\section{Considerações Finais}

$\mathrm{O}$ artigo, em linhas gerais, buscou analisar, a partir de uma perspectiva alternativa, cognitiva, alguns dos desafios enfrentados no esforço de se estabilizar, satisfatoriamente, o Estado haitiano, após as sucessivas crises institucionais pelos quais passou e as resultantes ações externas direcionadas a promover o State Building no país, a partir do mandato da MINUSTAH.

Nesse sentido, retomando a pergunta de pesquisa que norteou este estudo - como e em que medida o prisma atitudinal haitiano e as imagens resultantes interferiram na evolução do desenvolvimento das agendas propostas no mandato da MINUSTAH? - observou-se que a absorção de alguns elementos do prisma atitudinal presentes na história do país e, aqui identificados, foram levados em consideração nas imagens projetadas tanto por meio da MINUSTAH como nos processos decisórios políticos haitianos.

De maneira geral, os elementos recorrentes nesse processo foram: desarticulação política, autoritarismo governamental, desgaste das Forças Armadas haitianas e de segurança nacionais e a noção da necessidade de reforma das instituições políticas, econômicas e de segurança no Haiti.

Essa assimilação permitiu avanços em termos de estabilização da MINUSTAH no país. No entanto, outras variáveis que, em alguma medida, apresentavam potencial de interferência no desenvolvimento das propostas das Nações Unidas para o Haiti como: corrupção generalizada, o papel agregador do vodu, desavenças e desigualdades raciais entre negros e mulatos, dificuldade na coordenação de uma agenda comum em prol dos interesses nacionais e organização social centrada no seio familiar (individualismo) não foram devidamente consideradas na operação de paz.

Reconhecemos que essas variáveis são apenas parte de uma equação muito mais complexa, contudo, sua ausência nos planos de ação executados ajudam a explicar, ainda que parcialmente, alguns problemas como: a dificuldade em melhorar indicadores socioeconômicos, realizar eleições regulares, justas e livres e, até, em se conseguir inserir a promoção dos Direitos Humanos (bem como o combate a sua violação) como uma política pública no país caribenho. 
Outro elemento analisado foram as correlações entre as imagens projetadas pela ONU e pelos presidentes que o Haiti teve no período (2004-2016). Em geral, elas, as imagens, convergiram, principalmente, na percepção de: a) um país marginalizado e dependente da ajuda externa, b) que quer fazer uma reestruturação de suas instituições, e; c) concretizar a sua estabilidade política e democrática.

O alinhamento dessas imagens, por sua vez, também colaborou para que a MINUSTAH pudesse operar no Haiti. Por outro lado, imagens divergentes - como com relação aos Direitos Humanos - concorreram para que as ações planejadas não alcançassem plenamente os resultados esperados.

Logo, o distanciamento entre a percepção onusiana - que conferia crescente importância ao tema dos Direitos Humanos - e o irredutível discurso por parte da elite decisória haitiana ressaltando a necessidade imediata de desenvolvimento, sobretudo, econômico, protelou o cumprimento das agendas propostas, especialmente, após o terremoto que atingiu o país em 2010.

Portanto, a hipótese levantada de que quanto maior for a convergência entre elementos constituintes do ambiente psicológico (como o prisma atitudinal e as imagens construídas) maiores serão seus efeitos no desenvolvimento das agendas propostas no âmbito das operações de paz, no caso da MINUSTAH demonstrou ser válida, porém, com ressalvas que apontam a imprescindibilidade de análises mais profundas acerca do papel de variáveis outras que, por opção metodológica, aqui não foram consideradas.

É o caso, por exemplo, da necessidade de reforma das forças policiais. Apesar das projeções das elites decisórias e da ONU convergirem nesse aspecto, ainda assim, a aposição das imagens não foi suficiente para dirimir, durante a MINUSTAH, os problemas identificados e, tampouco, evitar que uma nova missão - a MINUSJUSTH - fosse estabelecida com o objetivo precípuo de fortalecer a Polícia Nacional e as instituições judiciais e penais do país.

Isso porque, como visto, houve, e há, enormes desafios que, sobrepostos em multifacetadas frentes (política, diplomática, militar, humanística), demandam soluções igualmente multiformes, que não se limitem aos aspectos cognitivos resultantes do prisma atitudinal, mas que, também, não os desconsiderem nos processos de tomada de decisão na complexidade da situação haitiana. 


\section{Referências Bibliográficas}

ALEXANDRE, Boniface. Discours du Président de La République, Me. Boniface Alexandre (2004).

Disponível

em:

$<$ http://haiticci.undg.org/uploads/discours\%20decloture\%20du\%20president\%2022-04.pdf> Acesso em: 23 mar. 2016.

Discours de Son Excellence Mâ̂tre Boniface Alexandre Président Provisoire de la République d'Haïti à la 60ème Session Ordinaire de l'Assemblée générale des Nations Unies. Disponível em: <https://webcache.googleusercontent.com/search?q=cache:yDXQVdBnBw4J:https://www.un. int/haiti/sites/www.un.int/files/Haiti/discours_de_son_excellence_maitre_boniface_alexandre _president_provisoire_de_la_republique_dhaiti_a_la_60eme_session_ordinaire_de_lassembe e_generale_des_nations_unies.doc $+\& c d=1 \& h l=p t-B R \& c t=c l n k \& g l=b r>$ Acesso em: 23 mar. 2016.

BOULDING, Kenneth. The image knowledge in life and society. Michigan: University of Michigan Press, 1961.

BRECHER, Michael. The Foreign Policy System of Israel Setting Images Process. New Haven: Yale University Press, 1972.

BRECHER, Michael; STEINBERG, Blema; STEIN, Janice. “A Framework for Research on Foreign Policy Behaviour”. Journal of Conflict Resolution, v. 13, nº1, pp. 75-101, 1969.

CIA. Haiti. Disponível em: <https://www.cia.gov/library/publications/the-worldfactbook/geos/ha.html>. Acesso em: 18 mar. 2016.

DORN, A. Walter. "Intelligence-led Peacekeeping: The United Nations Stabilization Mission in Haiti (MINUSTAH), 2006-07”. Journal of Intelligence and National Security, v.24, n6, p.805-835, 2009.

FILHO, Manoel Souza D’Agrella. Física da terra e do universo para licenciaturas em geociências. Disponível em: http://www.iag.usp.br/ agg_1400200/moddata/GEOFISICA/apostila2-sismo.pdf >. Acesso em: 20 mar. 2016.

FUKUYAMA, Francis. Construção de Estados: governo e organização mundial no século XXI. Rio de Janeiro: Rocco, 2005.

FUND FOR PEACE. Fragil States Index. Disponível em: <http://fundforpeace.org/fsi/>. Acesso em: 18 mar. 2016. 
GOMES, Áureo Toledo. "Nation-Building e Segurança Internacional: um debate em construção". Contexto Internacional. Rio de Janeiro, 31(2), 2009, p.285-313.

GORENDER, Jacob. “O épico e o trágico na história do Haiti”. Estudos Avançados, v. 18, n. 50, p. 295-302, 2004.

HAMANN, Eduarda. "United Nations Presence in Haiti: Challenges of a multidimensional Peacekeeping mission". Conflict Trends, Issue 4, p. 38-45, 2009.

HARRISON, Lawrence E. Subdesenvolvimento é um Estado de Espírito. Tradução Haroldo Netto. São Paulo: Record, 1985.

HEINE, Jorge; THOMPSON, Andrew S. Fixing Haiti: MINUSTAH and Beyond. New York: United Nations University Press, 2011.

HELMAN, Gerald; RATNER, Steven. "Saving Failed States”. Foreign Policy, Issue 89, pp. 3-18, 1992.

HERZ, Mônica. "Análise Cognitiva e Política Externa”. Contexto Internacional, v.16, n.1, p.75-89, 1994.

ICI RADIO CANADA. René Préval demande de l'aide. Disponível em: <http://ici.radiocanada.ca/nouvelles/International/2006/03/27/005-ONU-haiti-preval.shtml>. Acesso em: 18 mar. 2016.

JACKSON, Robert. Surrogate Sovereignty? Great Power Responsibility and "Failed States". The University of British Columbia, Institute of International Relations Working Paper No.25, November 1998.

JUNIOR, Almir de Oliveira; GÓES, Fernanda Lira. "A presença brasileira nas Operações de Paz das Nações Unidas". Texto para discussão, n.1516, IPEA, 2010.

LAGUERRE, Michel S. Voodoo and Politics in Haiti. Basingstoke: Macmillan, 1989.

LAZIER, Tiago Cerqueira. "Eleições são realizadas no Haiti, após quatro adiamentos". Conjuntura Internacional, v.3, n. 1, p. 7-9, 2006.

MARTELLY, Michel Joseph. Discours a la 32ème Réunion ordinaire de la Conférence des Chefs d'Etat et de Gouvernement de la CARICOM. Disponível em: $<$ http://www.francophonie.org/Discours-de-Joseph-Michel-Martelly.html> Acesso em: 23 mar. 2016.

Discours du Président Martelly devant l'Assemblée Nationale (2012). Disponível em: $<$ http://lenouvelliste.com/lenouvelliste/article/126226/Discours-Du-President-de-laRepublique.html> Acesso em: 23 mar. 2016. 
Discours du Président Martelly à la tribune de l'ONU. Disponível em: $<$ http://www.haitilibre.com/article-15318-haiti-flash-discours-du-president-martelly-a-latribune-de-l-onu.html> Acesso em: 23 mar. 2016.

ONU. MINUSTAH: United Nations Stabilization Mission in Haiti. Disponível em: <http://www.un.org/en/peacekeeping/missions/minustah/>. Acesso em: 25 fev. 2016.

Conselho de Segurança aprova fim da missão da ONU no Haiti. Disponível em: $<$ https://nacoesunidas.org/conselho-de-seguranca-aprova-fim-da-missao-da-onu-no-haiti/> Acesso em: 20 abr. 2017.

PETRUS, Gabriel Merheb. O Haiti como Estado falido: da exportação de democracia à reconstrução institucional. Dissertação (Mestrado em Relações Internacionais) - UnB. Brasília, 2012.

POPKIN, Jeremy D. A Concise History of the Haitian Revolution. Chichester: WileyBlackwell, 2011.

PRÉVAL. René. Texte intégral du discours du Président René Préval devant la 62e Assemblée générale de l'ONU (2006). Disponível em: 〈http://radiokiskeya.com/spip.php?> Acesso em: 23 mar. 2016.

Discours de René Préval à la 64e Assemblée générale de l'ONU (2009). Disponível em: <http://www.voltairenet.org/article162285.html> Acesso em: 23 mar. 2016.

.Discours du président René Préval à la conférence internationale des donateurs intitulée "Vers un nouveau futur pour Haïti (2010). Disponível em: <http://radiotelevision2000.com/home/?p=3571> Acesso em: 23 mar. 2016.

QUEIROZ, Fabio Albergaria. "Dinâmicas do processo decisório em política externa a partir de uma perspectiva cognitiva: o papel das imagens no caso da Política Externa Independente (1961-1964).” Política Externa, v.22, n.2, pp.25-38, 2013.

ROCHA, Antonio Jorge Ramalho. Operações de paz em situações de conflito: como e até quando intervir. In: ENCONTRO NACIONAL DE ESTUDOS ESTRATÉGICOS, 7. Brasília: 2007

SECURITY COUNCIL. Resolution 1743 (2007). Disponível em: <http://www.un.org/en/ga/search/view_doc.asp?symbol=S/RES/1743(2007)>. Acesso em: 12 mar. 2016.

- Resolution 1840 (2008). Disponível em:

<http://www.un.org/en/ga/search/view_doc.asp?symbol=S/RES/1840(2008)>. Acesso em: 12 mar. 2016. 
Resolution 1892 (2009). Disponível em: <http://www.securitycouncilreport.org/undocuments/document/Haiti\%20SRES\%201892.php>. Acesso em: 12 mar. 2016.

Resolution $2012 \quad$ (2011). Disponível

em:

<http://www.un.org/en/ga/search/view_doc.asp?symbol=S/RES/2012(2011)>. Acesso em: 12 mar. 2016.

$$
\text { Resolution } 2070 \text { (2012). Disponível em: }
$$

<http://www.un.org/en/ga/search/view_doc.asp?symbol=S/RES/2070(2012)>. Acesso em: 12 mar. 2016.

. Statement by the President of the Security Council (2005). Disponível em: $<$ http://www.un.org/en/ga/search/view_doc.asp?symbol=S/PRST/2005/1> Acesso em: 12 mar. 2016.

SEITENFUS, Ricardo. Haiti: Dilemas e Fracassos Internacionais. Rio Grande do Sul: Unijuí, 2014.

SILVA, Alexandra de Mello.“O Brasil no Continente e no Mundo: Atores e Imagens na Política Externa Brasileira Contemporânea”. Estudos Históricos, v.8, n.15, 1995, p.1-38.

SPROUT, Harold; SPROUT, Margaret. "Environmental Factors in the Study of International Politics”. Journal of Conflict Resolution, vol. 1, n.4, 1957, p.309-28.

TAFT-MORALES, Maureen. Haiti Under President Martelly: Current Conditions and Congressional Concerns (2015). Disponível em: 〈https://fas.org/sgp/crs/row/R42559.pdf> Acesso em 15 dez 2017.

Haiti's Political and Economic Conditions: In Brief (2017). Disponível em: < https://fas.org/sgp/crs/row/R45034.pdf> Acesso em 15 dez 2017.

VIANA, Suhayla Mohamed Khalil. A Minustah e participação brasileira. Disponível em: <https://sensocomum.xanta.org/index.php/revista/article/view/6/4> Acesso em 15 dez 2017.

\section{Uma Abordagem Cognitiva sobre o Haiti: o papel do ambiente psicológico na construção de imagens no contexto da MINUSTAH (2004-2016)}

\section{Resumo}

O artigo realiza um estudo sobre o ambiente psicológico do Haiti a partir da interação entre duas variáveis cognitivas: prisma atitudinal e imagem. Nesse sentido, com base na literatura sobre modelo de análise em processo decisório, assumimos a premissa de que elementos cognitivos (como ideias e percepções construídas ao longo da história) são tão importantes na definição de planos de ação quanto as tradicionais variáveis objetivas tais como aporte financeiro. Para tanto, testamos as proposições desse modelo no caso da Missão das Nações Unidas para Estabilização do Haiti (MINUSTAH), de 2004, ano de seu início, até 2016. A partir da análise amostral de discursos presidenciais e, também, de resoluções do mandato da ONU, testou-se a hipótese de que 
quanto maior for a convergência das imagens entre os tomadores de decisão externos e internos, maiores serão as chances de uma missão de paz, neste caso a MINUSTAH, alcançar seus objetivos.

Palavras-Chave: Abordagem Cognitiva. Prisma Atitudinal. Imagens. MINUSTAH.

\title{
Un enfoque cognitivo sobre Haití: el papel del ambiente psicológico en la construcción de imágenes en el contexto de la MINUSTAH (2004-2016)
}

\section{Resumen}

El artículo realiza un estudio sobre el ambiente psicológico de Haití a partir de la interacción entre dos variables cognitivas: prisma de actitud e imagen. En este sentido, con base en la literatura sobre modelo de análisis en proceso decisorio, asumimos la premisa de que elementos cognitivos (como ideas y percepciones construidas a lo largo de la historia) son tan importantes en la definición de planes de acción como las tradicionales variables objetivas tales como aporte financiera. Para eso, investigamos las proposiciónes de este modelo en el caso de la Misión de las Naciones Unidas para la Estabilización de Haití (MINUSTAH), de 2004, año de su inicio, hasta 2016. A partir del análisis de muestreos de discursos presidenciales y también de resoluciones del mandato de la ONU, se pone a la prueba la hipótesis de que cuanto mayor sea la convergencia de las imágenes entre los tomadores de decisión externos e internos, mayores serán las posibilidades de una misión de paz, en este caso la MINUSTAH, alcanzar sus objetivos.

Palabras clave: Enfoque cognitivo. Prisma Actitudinal. Imagen. MINUSTAH.

\section{Uma Abordagem Cognitiva sobre o Haiti: o papel do ambiente psicológico na construção de imagens no contexto da MINUSTAH (2004-2016)}

\begin{abstract}
The article was aimed at studying the psychological environment of Haiti from the interaction between two cognitive variables: the so-called attitudinal prism and image. In this sense, based on the literature on decisionmaking analysis, we assumed the premise that cognitive elements (such as ideas and perceptions built throughout history) are as important in defining plans of action as traditional objective variables such as financial aid. To that end, we tested the propositions of this model in the case of the United Nations Stabilization Mission in Haiti (MINUSTAH), from its beginning, in 2004, to 2016. Based on the analysis of presidential speeches and also on UN mandate resolutions samples, we tested the hypothesis that the greater the convergence of images between external and internal decision makers, the greater the likelihood of a peace mission achieve its goals.
\end{abstract}

Keywords: Cognitive Approach. Attitudinal Prism. Images. MINUSTAH. 